\title{
Impact of nanoparticles and butanol on properties and spray characteristics of waste cooking oil biodiesel and pure rapeseed oil
}

\author{
K. H. Ahmad and A. K. Hossain* \\ Sustainable Environment Research Group, Aston University, Birmingham B4 7ET, UK \\ *Corresponding author email: a.k.hossain@aston.ac.uk
}

\begin{abstract}
Renewable biofuels can offset greenhouse gases by replacing fossil fuels destined for internal combustion engines. However, biofuels have their own setbacks and may lead to poor combustion inside the engine cylinder. In this study, nanoparticles and butanol were blended either separately or together with waste cooking oil biodiesel and neat rape seed oil to investigate the impact of these additives on the properties and spray characteristics. The investigation comprised of three stages, with each having an effect on how the next stage of the investigation was conducted. Initially, the physicochemical characteristics of $25 \mathrm{ppm}, 50 \mathrm{ppm}, 75 \mathrm{ppm}$ and $100 \mathrm{ppm}$ concentrations of aluminium oxide and copper oxide nanoparticle blends with fossil diesel, waste cooking oil biodiesel and rapeseed oil were investigated. The results from first stage investigation showed that, in general, blends containing aluminium oxide nanoparticles gave better results for almost all the concentrations when compared with copper oxide nanoparticle blends with the same nanoparticle concentrations. Overall, waste cooking oil biodiesel blended with 100ppm aluminium oxide nanoparticle showed most promising results like the flash point of $159.3^{\circ} \mathrm{C}$, kinematic viscosity@40 $40^{\circ} \mathrm{C}$ of $4.66 \mathrm{cSt}$, and gross calorific value of $44.43 \mathrm{MJ} / \mathrm{kg}$. These values were 61.6\% higher, 51.3\% higher and 3.2\% lower than that of corresponding fossil diesel values. Subsequently, in the second stage of the study, the addition of butanol was investigated to assess its ability to enhance the emulsion of biofuel-nanoparticles blends. Four blends containing $90 \%$ biodiesel \& $10 \%$ butanol, and $90 \%$ rapeseed oil \& $10 \%$ butanol, with and without $100 \mathrm{ppm} \mathrm{Al}_{2} \mathrm{O}_{3}$ were prepared. Results showed that the kinematic viscosity of the fuel blends containing $100 \mathrm{ppm}$ aluminium oxide nanoparticles were decreased by $0.4 \%$ and $3.3 \%$, for $90 \%$ biodiesel \& $10 \%$ butanol and $90 \%$ rapeseed oil \& 10\% butanol blends respectively, when compared to without the nanoparticles. The results obtained from the second stage of investigation proved that butanol acted as a surfactant and thus addition of butanol helped to improve the properties of the biofuelnanoparticle blends. In the third stage of the study, the spray characteristics of fossil diesel, biodiesel, biodiesel $+100 \mathrm{ppm}$ aluminium oxide nanoparticles, rapeseed oil, rapeseed oil $+100 \mathrm{ppm}$ aluminium oxide nanoparticles, $90 \%$ biodiesel \& 10\% butanol, $90 \%$ biodiesel \& $10 \%$ butanol + $100 \mathrm{ppm}$ aluminium oxide nanoparticles, $90 \%$ rapeseed oil \& $10 \%$ butanol and $90 \%$ rapeseed oil \& $10 \%$ butanol $+100 \mathrm{ppm}$ aluminium oxide nanoparticles were investigated. It was found that amongst all fuels, blend containing $90 \%$ biodiesel $+10 \%$ butanol $+100 \mathrm{ppm}$ aluminium oxide nanoparticles gave better spray characteristics; for example, the liquid sheet angle was $7.14 \%$ lower and the spray cone angle was $7.87 \%$ higher than the corresponding fossil diesel values. The study concluded that the spray characteristics and properties of biofuels could be improved by blending with both aluminium oxide nanoparticles and butanol.
\end{abstract}

Keywords: Nanoparticle, Butanol, Biofuel, Properties, Spray characteristics, CI Engine 


\section{INTRODUCTION}

The increase in the energy demand, global warming, limited reserve of fossil fuels and refinery capacity have alarmed the world to harvest into green methods of producing energy. Scientists and researchers have been trying to find ways to reducing harmful emissions of internal combustion (IC) engines by modifying them, using alternative fuels, blending different fuels together and using additives [1]. Biofuels can be used in compression ignition (CI) engines and they may be produced domestically. However, they have their own setbacks as being highly viscous, less stable and incompatible with the existing fuel supply systems. One approach to improve the biofuels properties is by addition of nanoparticles; but currently there are concerns if the nanoparticles does not burn inside the engine cylinder and their effect on the exhaust emission gases, fuel pump, fuel filter and fuel injection characteristics [2]. Nanoparticles have a higher surface area to volume ratio, which acts as a highly reactive catalysts [3]. Aluminium oxide nanoparticles have the ability to donate their oxygen atoms from its lattice structure to the fuel which enhances combustion characteristics [4]. Lower NOx and soot emission can be achieved by addition of nanoparticles [2, 5]; Samuel and Shefeek [6] investigated the effects of cerium oxide nanoparticles addition in fossil diesel (FD) on performance and emission characteristics of a four cylinder CI engine. An ultrasonic shaker was used to mix the nanoparticles with FD. Four blends of FD were made with $10 \mathrm{ppm}, 20 \mathrm{pmm}, 30 \mathrm{ppm}$ and $40 \mathrm{ppm}$ of nanoparticles. It was observed that the specific fuel consumption was decreased as cerium oxide nanoparticles acted as an oxygen donating catalyst which enhanced combustion characteristics. $\mathrm{CO}$ and nitrogen gases reduced from $2 \%$ to $1.4 \%$ and from $83 \%$ to $81.6 \%$ respectively, with 40ppm cerium oxide nanoparticles blend when compared to neat FD [6]. Gumus et al. [7] assessed the impacts of aluminium oxide nanoparticles $\left(\mathrm{Al}_{2} \mathrm{O}_{3}\right)$ and copper oxide nanoparticles $\left(\mathrm{C}_{\mathrm{u}} \mathrm{O}\right)$ on $\mathrm{FD}$; they investigated the physicochemical properties, stability of nanoparticles in the FD with the use of various surfactants, and CI engine performance \& emissions. Nanoparticles blends of 50ppm with FD for both nanoparticles were created using an ultrasonic mixer. The emulsion of nanoparticles in diesel was tested using two different surfactants (Sodium Silicate and Darvan-C). They reported that 2\% Darvan-C showed the best emulsion layer [7]. Santhanamuthu et al. [8] investigated the performance and exhaust emissions of a $\mathrm{CI}$ engine with blends of polanga seed oil, FD and iron oxide nanoparticles. They observed best optimum engine performance with $100 \mathrm{ppm}$ iron oxide nanoparticles. D'silva et al. [9] added titanium oxide nanoparticles $\left(\mathrm{T}_{\mathrm{i}} \mathrm{O}_{2}\right)$ in $\mathrm{FD}$ to investigate stable dispersion, engine performance and emission characteristics. They reported that the flash point, fire point, kinematic viscosity, density and calorific value were increased with the addition of $\mathrm{T}_{\mathrm{i}} \mathrm{O}_{2}$ by $41.17 \%, 40.74 \%, 6.17 \%, 0.43 \%$ and $0.59 \%$ 
respectively [9]. About $21.28 \%$ reduction in brake specific fuel consumption (bsfc) was observed at peak load when $\mathrm{T}_{\mathrm{i}} \mathrm{O}_{2}$ were added. Other studies also reported improvement in fuels properties when blended with nanoparticles [10-12]. However, in some cases decrease in the calorific value was also reported [6]. Kinematic viscosity increased with the addition of nanoparticles, but the use of surfactants allowed the nanoparticles to emulsify in the base fuel properly, hence decrease in the viscosity was also reported [7]. Spray characteristics of neat biofuels were investigated [13-14]. Wang et al. [13] investigated the spray characteristics of biodiesels produced from waste cooking oil, palm oil and FD at various injection pressures. Biodiesels gave longer spray tip penetration with injection delays, smaller projected area, less volume and smaller spray angle than FD. With increased injection pressure, the difference between the sauter mean diameter (SMD) of biodiesel and FD was decreased. Butanol was found to be a suitable additive for biofuels for improved engine performance and reduced emission gases [15-16]. In this study, the effect of butanol addition on physicochemical and spray characteristics of biofuel-nanoparticles blends will be investigated. The study will be conducted in three stages: (i) two nanoparticles $\left(\mathrm{C}_{\mathrm{u}} \mathrm{O}\right.$ and $\left.\mathrm{Al}_{2} \mathrm{O}_{3}\right)$ will be used to blend separately with FD, waste cooking oil biodiesel (B100) and neat rapeseed oil (RSO100); physicochemical properties will be measured and compared to find the optimum nanoparticles blends (ii) butanol will be added into the optimum nanoparticles blends, and the effectiveness of butanol as surfactant will be assessed by comparing the properties of the butanol-nanoparticles-biofuel blends (iii) spray characteristics of the fuel blends will be measured and analysed. Finally, properties and spray characteristics will be compared to find the optimum blends for $\mathrm{CI}$ engine testing.

\section{MATERIALS AND METHODS}

Waste cooking oil biodiesel (B100) was acquired from a local company, and rape seed oil (RSO100) was acquired from supermarket. The nanoparticles were purchased from Sigma-Aldrich. Butanol (1 Butane) was purchased from Fisher Scientific Ltd. The study was carried out in three stages: (i) Firstly, to investigate the blends of FD, B100 (from WCO) and RSO100 with $\mathrm{Al}_{2} \mathrm{O}_{3}$ and $\mathrm{C}_{\mathrm{u}} \mathrm{O}$ nanoparticles to find out which of the two nanoparticles was more feasible to be used and also in what concentration, (ii) Secondly, to investigate if the Butanol could be used as an emulsifier when nanoparticles were mixed with the fuel, and (iii) Finally, to investigate the effects of nanoparticles and butanol on macroscopic spray characteristics of the fuel blends. Parr 6100 Bomb Calorimeter (ASTM-D240),

Setaflash series 3 plus closed cup flash point tester (ASTM-D3278), and Cannon Fenski u-tube viscosity meter (ASTM-D130) were used to measure the heating 
value, flash point temperature and kinematic viscosities of the fuel blends. Kinematic viscosity was measured at $@ 40^{\circ} \mathrm{C}$ using a constant temperature water bath. The density was measured using hydrometer and volume-weight method. Fuel blends samples for all the three base fuels (FD, B100 and RSO100) with 25ppm, $50 \mathrm{ppm}, 75 \mathrm{ppm}$ and $100 \mathrm{ppm}$ concentrations of both nanoparticles $\left(\mathrm{Al}_{2} \mathrm{O}_{3}\right.$ and $\left.\mathrm{C}_{\mathrm{u}} \mathrm{O}\right)$ by mass were prepared. Physicochemical characteristics were measured. The results were analysed and compared, improved nanoparticles blends were taken for phase 2 study, where butanol was introduced - biofuel and butanol was mixed together and after that 100ppm the nanoparticle was added in the blend. The blends were shaken for 15 minutes so the nanoparticles could be dispersed into the blends properly. Macroscopic spray characteristics of fuel injection (liquid sheet angle and spray cone angle) were measured using optical and mechanical methods. Sealey VS2058 diesel injector nozzle POP tester and Lister Petter fuel injector (P751-62090) manufacture by Delphi were used (Figure 1). The maximum pressure of the POP tester was 600 bar and the opening pressure was 125 bar. The nozzle had a single hole through which the fuel was sprayed as a full cone (Figure 1). Liquid sheet angle is defined as the angle of the fuel as it comes out of the nozzle (Figure 2), before it turns into spray particles. An optical technique was used to measure the liquid sheet angle. Nikon D3320 camera was used to take the photographs of the fuel. All the photographs were taken from a specific point marked on the ground for accuracy. The spray cone angle is the angle at which the fuels starts dispersing from liquid into tiny molecular particles when injected from an injection nozzle. A mechanical technique of using a $445 \times 570$ blotting (absorbent) paper at a distance of $302 \mathrm{~mm}$ below the nozzle was used to find the indentation diameter on the blotting paper. The distance was selected in such a way so the fuel was allowed to form into tiny molecular 


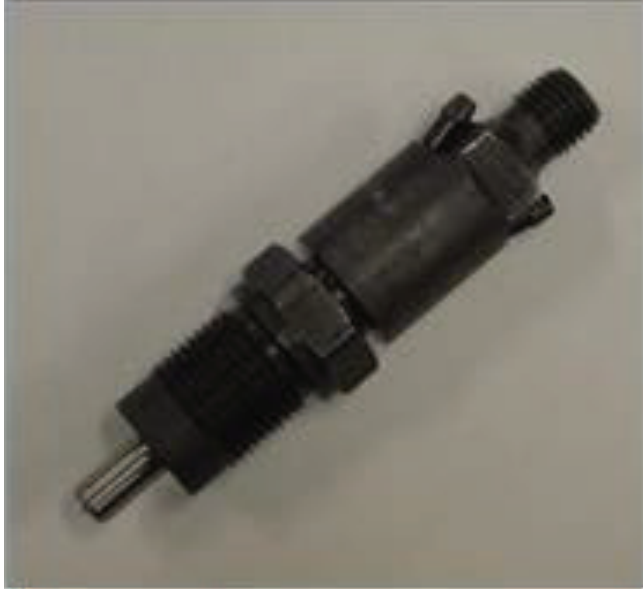

(a) Delphi injector

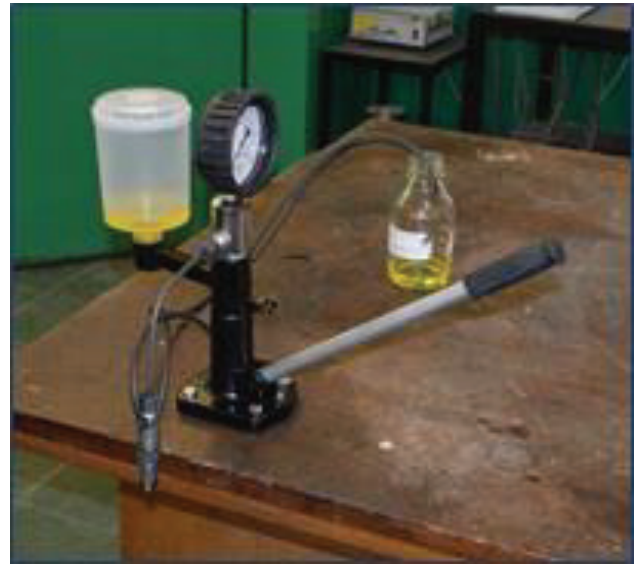

(b) POP tester

Figure 1 - The injector nozzle and POP tester setup

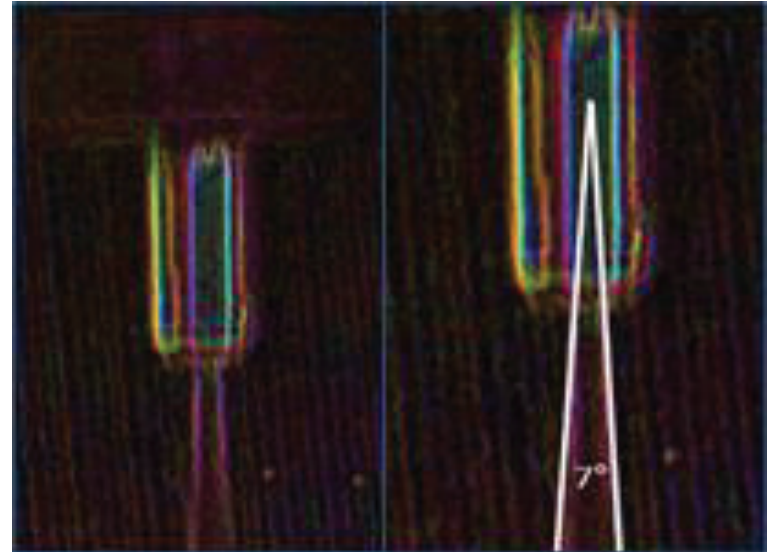

Figure 2 - Left: The edges sharpened of the magnified image, and Right: manually addition of lines on the edges to measure the liquid sheet angle, these images are for FD

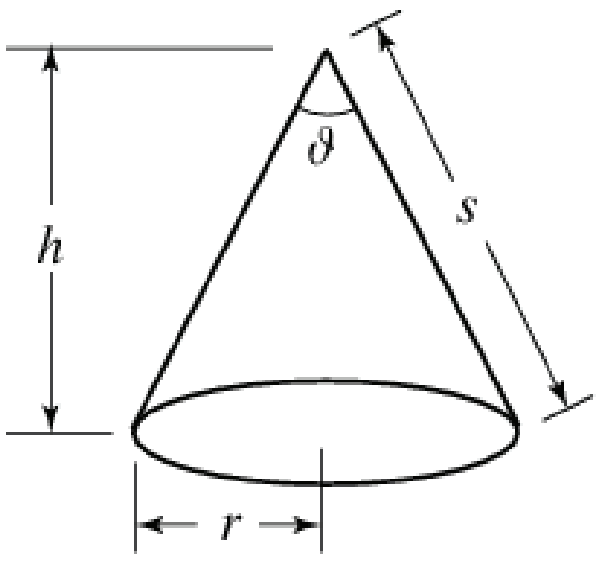

Figure 3 - Spray cone angle parameters [17]

particles. Platform was manually constructed so the blotting paper was as horizontal as possible, ensuring that indentation of the spray was accurate. The test was performed 5 times and the average value was taken. For each of the blends, the 
formula below was used to find the spray cone angle. Figure 3 shows the parameters of a cone used to estimate the spray cone angle using following equation:

$$
\text { Spray cone angle }\left(^{\circ}\right)=2 \times \tan ^{-1}\left(\frac{r}{h}\right)
$$

Where $r$ is the radius (of the indentation) and $\mathrm{h}$ is the height (distance from the nozzle tip to the blotting paper).

\section{RESULTS AND DISCUSSION}

Figure 4 illustrate the physicochemical properties of the neat fuels and blends when $\mathrm{CuO}$ and $\mathrm{Al}_{2} \mathrm{O}_{3}$ was added. Figures 4(a-c) shows comparison of the density [@1 $\left.15^{\circ} \mathrm{C}\right]$ of nanoparticles blends with respect to the neat FD, B100 and RSO100 fuels. The density of $\mathrm{CuO}$ and $\mathrm{Al}_{2} \mathrm{O}_{3}$ are $6.4\left(\frac{\mathrm{g}}{\mathrm{m}^{3}}\right)$ [18] and $3.7\left(\frac{\mathrm{g}}{\mathrm{m}^{3}}\right)$ [19]; hence, density increase due to $\mathrm{C}_{\mathrm{u}} \mathrm{O}$ addition was higher than $\mathrm{Al}_{2} \mathrm{O}_{3}$. In general, density of all blends were increased in the range of $0.07 \%$ to $0.13 \%$ as the nanoparticles concentration was increased from $25 \mathrm{ppm}$ to $100 \mathrm{ppm}$. The flash point of neat RSO100 fuel was maximum; flash point for blends of $\mathrm{Al}_{2} \mathrm{O}_{3}$ and $\mathrm{C}_{\mathrm{u}} \mathrm{O}$ with $\mathrm{FD}$ increased as the concentration of the nanoparticles increased up to $75 \mathrm{ppm}$. The flash point temperature stayed constant from $75 \mathrm{ppm}$ to $100 \mathrm{pm}$ (Figure 4(d)). Almost similar trend was also observed for B100 fuel (Figure 4(e)). In the case of RSO100 and blends, for $\mathrm{Al}_{2} \mathrm{O}_{3}$ nanoparticle, the flash point stayed constant up to $75 \mathrm{ppm}$ and then increased by $0.19 \%$ when the concentration was increased to $100 \mathrm{ppm}$. However, for $\mathrm{C}_{\mathrm{u}} \mathrm{O}$, the trend was not clear possibly due to the non-homogeneous mixing of nanoparticles (Figure 4(f)). 


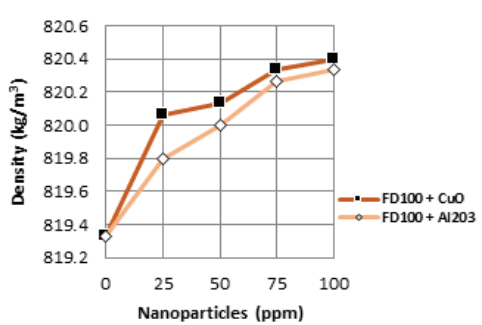

(a) Density of Fossil Diesel \& blends

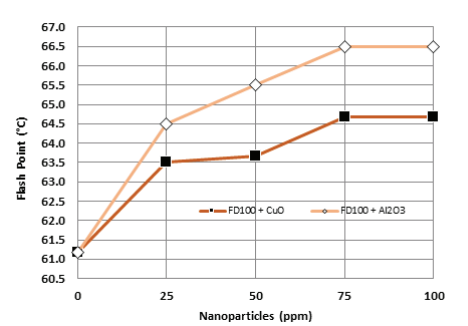

(d) Flash point of Fossil Diesel \& blends

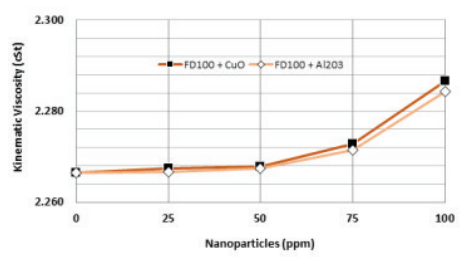

(g) Fossil Diesel \& blends @ $40^{\circ} \mathrm{C}$

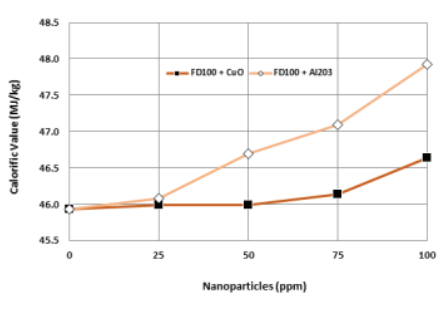

(j) HHV of Fossil Diesel \& blends

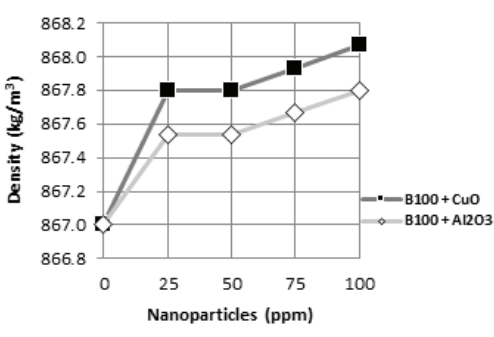

(b) Density of B100 \& blends

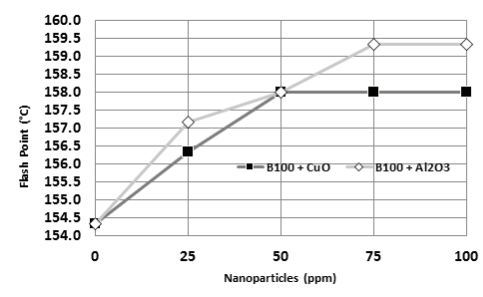

(e) Flash point of $\mathrm{B} 100 \&$ blends

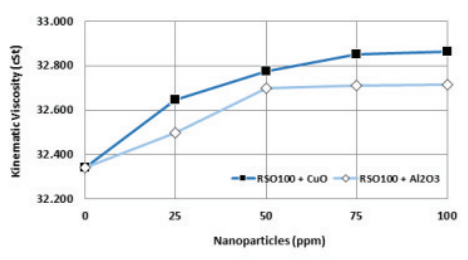

(h) B100 \& blends @ $400^{\circ} \mathrm{C}$

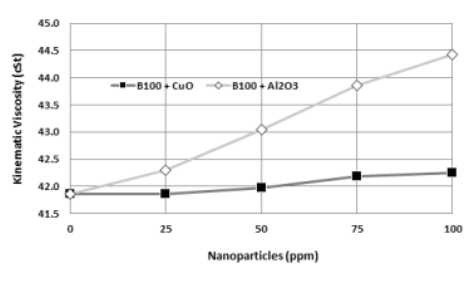

(k) HHV of B100 \& blends

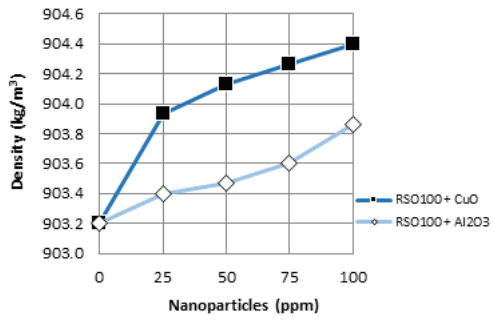

(c) Density of RSO100 \& blends

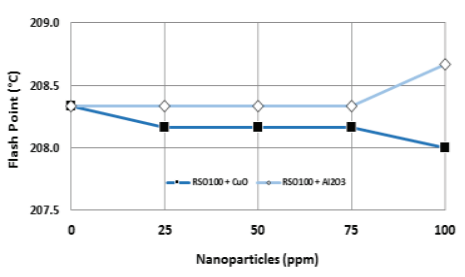

(f) Flash point of RSO100 and blends

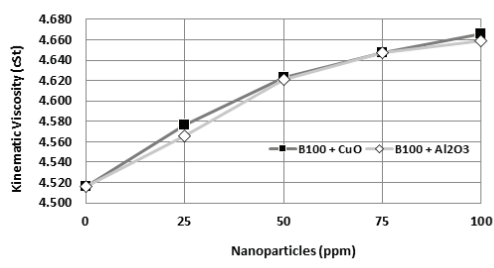

(i) RSO100 \& blends $@ 40^{\circ} \mathrm{C}$

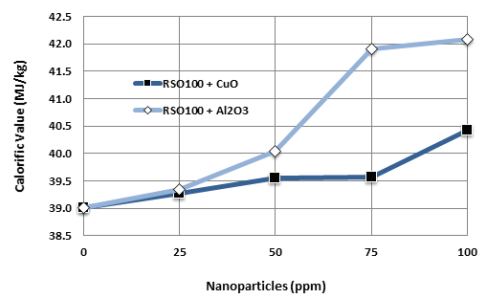

(1) HHV of RSO100 \& blends

Figure 4 - Physicochemical properties of $\mathrm{Al}_{2} \mathrm{O}_{3}$ and $\mathrm{CuO}$ nanoparticle blends 
For all nanoparticle blends of FD, B100 and RSO10O, the kinematic viscosity increased with increased concentration of nanoparticles (Figures $4(\mathrm{~g}-\mathrm{i})$. $\mathrm{CuO}$ caused higher kinematic viscosity in comparison to $\mathrm{Al}_{2} \mathrm{O}_{3}$ in all the cases. It was believed that this was due to the higher density of the $\mathrm{CuO}$ than $\mathrm{Al}_{2} \mathrm{O}_{3}$ blends. In addition, nanoparticles increases the surface tension in the fuel blends [20], with increased concentration of nanoparticles, the surface tension would also increase and hence the viscosity. The calorific value increased with increased concentration of nanoparticles (Figure 4(j-1)). For all blends and for same concentration of nanoparticles, $\mathrm{Al}_{2} \mathrm{O}_{3}$ gave higher $\mathrm{HHV}$ than $\mathrm{CuO}$. The increase in $\mathrm{HHV}$ of RSO100 when $100 \mathrm{ppm} \mathrm{Al}_{2} \mathrm{O}_{3}$ was added was $7.3 \%$; whereas, these values were $5.8 \%$ and $4.1 \%$ for $\mathrm{B} 100$ and FD respectively (Figure $4(\mathrm{j}-1)$ ). Furthermore, it was found that calorific value of $\mathrm{B} 100$ with $100 \mathrm{ppm} \mathrm{Al}_{2} \mathrm{O}_{3}$ is almost similar to that of neat $\mathrm{FD}$. Higher oxygen content in $\mathrm{Al}_{2} \mathrm{O}_{3}$ caused higher $\mathrm{HHV}$ than $\mathrm{CuO}$, as oxygen helps in combustion. On the basis of the above results, eight more blends were prepared using $100 \mathrm{ppm} \mathrm{Al}_{2} \mathrm{O}_{3}$ nanoparticle and 10\% Butanol : 90\% B100 \& 10\% Bu (B90Bu10), $90 \% \mathrm{~B} 100 \& 10 \% \mathrm{Bu}+100 \mathrm{ppm} \mathrm{Al}_{2} \mathrm{O}_{3}\left(\mathrm{~B} 90 \mathrm{Bu} 10+100 \mathrm{ppm} \mathrm{Al}_{2} \mathrm{O}_{3}\right), 90 \% \mathrm{RSO} 100$ $\& 10 \% \mathrm{Bu}(\mathrm{RSO} 00 \mathrm{Bu} 10), 90 \% \mathrm{RSO} 100 \& 10 \% \mathrm{Bu}+100 \mathrm{ppm} \mathrm{Al}_{2} \mathrm{O}_{3}(\mathrm{RSO} 90 \mathrm{Bu} 10$ $\left.+100 \mathrm{ppm} \mathrm{Al}_{2} \mathrm{O}_{3}\right), 80 \% \mathrm{~B} 100 \& 20 \% \mathrm{Bu}(\mathrm{B} 80 \mathrm{Bu} 20), 80 \% \mathrm{~B} 100 \& 20 \% \mathrm{Bu}+$ $100 \mathrm{ppm} \quad \mathrm{Al}_{2} \mathrm{O}_{3}\left(\mathrm{~B} 80 \mathrm{Bu} 20+100 \mathrm{ppm} \quad \mathrm{Al}_{2} \mathrm{O}_{3}\right), \quad 80 \% \quad \mathrm{RSO} 100 \quad \& \quad 20 \% \mathrm{Bu}$ $(\mathrm{RSO} 80 \mathrm{Bu} 20)$ and $80 \% \mathrm{RSO} 100 \& 20 \% \mathrm{Bu}+100 \mathrm{ppm} \mathrm{Al}_{2} \mathrm{O}_{3}(\mathrm{RSO} 80 \mathrm{Bu} 20+$ 100 ppm $\mathrm{Al}_{2} \mathrm{O}_{3}$ ).

The emulsions of the nanoparticle blends were checked after 5 days of blend preparation and it could be seen that the $\mathrm{Al}_{2} \mathrm{O}_{3}$ particles had dispersed better with the use of butanol (Figure 5).

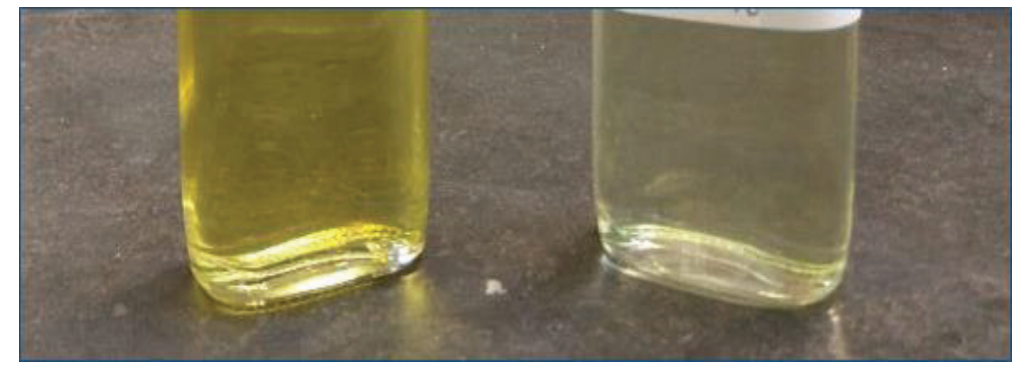

Figure 5 - Examples of a close up look of the blends after 5 days of $\mathrm{Al}_{2} \mathrm{O}_{3}$ nanoparticles addition

Figure 6 (a) shows the effect of butanol addition, for example, when $10 \%$ butanol was added to B100 (from B100 to B90Bu10) flash point was decreased by $58.1 \%$. 
The flash point of Butanol is $35^{\circ} \mathrm{C}$ [21] which caused this behaviour. However, this is still 5.4\% higher than FD. Similar behaviour was observed with RS100, the flash point was decreased by $66.7 \%$ when $10 \% \mathrm{Bu}$ was added (ie. from RSO100 to RSO90Bu10).

Flash point temperatures were increased when 100ppm $\mathrm{Al}_{2} \mathrm{O}_{3}$ was added. For example, flash point was increased by $3.4 \%$ for $\mathrm{B} 100$ fuel when $100 \mathrm{ppm} \mathrm{Al}_{2} \mathrm{O}_{3}$ was added, and in the case of $\mathrm{B} 90 \mathrm{Bu} 10$ fuel this was increased by $7.6 \%$. The increase in flash point for $\mathrm{RSO} 100$ when $100 \mathrm{ppm} \mathrm{Al}_{2} \mathrm{O}_{3}$ were added was $0.2 \%$ and the increase rate was 5.14\% for RSO90Bu10 fuel when $100 \mathrm{ppm} \mathrm{Al}_{2} \mathrm{O}_{3}$ was added. Furthermore, it was observed that percentage increase for B100 and RSO100 fuels when 100ppm $\mathrm{Al}_{2} \mathrm{O}_{3}$ were added was much lower than $\mathrm{B} 90 \mathrm{Bu} 10$ and RSO90Bu10. This proved that addition of butanol helped the nanoparticles to emulsify effectively. Kinematic viscosity of butanol $@ 40^{\circ} \mathrm{C}$ is $1.0039 \mathrm{cSt}$ [22].

When $10 \%$ butanol was added to B100, viscosity decreased by $15.2 \%$ (Figure $6(\mathrm{~b}$ c)). Similar characteristics were observed with RSO100 when $10 \% \mathrm{Bu}$ was added viscosity $@ 40^{\circ} \mathrm{C}$ was decreased by 39.7\%. The increase for B100 when 100ppm $\mathrm{Al}_{2} \mathrm{O}_{3}$ were added was $3.1 \%$. On the other hand, viscosity was decreased by $0.4 \%$ for $\mathrm{B} 90 \mathrm{Bu} 10$ fuel when $100 \mathrm{ppm} \mathrm{Al}_{2} \mathrm{O}_{3}$ was added. The percentage increase for RSO100 when $100 \mathrm{ppm} \mathrm{Al}_{2} \mathrm{O}_{3}$ were added was $1.1 \%$, whereas for RSO90Bu10 viscosity was decreased by $3.3 \%$ when $100 \mathrm{ppm} \mathrm{Al}_{2} \mathrm{O}_{3}$ were added. So, it was established that when $\mathrm{Al}_{2} \mathrm{O}_{3}$ nanoparticles were added to $\mathrm{B} 100$ and $\mathrm{RSO} 100$ the viscosity of the blends increased due to increased surface tension.

On the other hand, when 100ppm $\mathrm{Al}_{2} \mathrm{O}_{3}$ was added to $\mathrm{B} 90 \mathrm{Bu} 10$ and $\mathrm{RSO} 90 \mathrm{Bu} 10$ fuels, the viscosity decreased due to the fact that butanol acted as a surfactant and dispersed the $\mathrm{Al}_{2} \mathrm{O}_{3}$ into the blends properly. It was believed that the decrease in the viscosity of the biofuel $+10 \% \mathrm{Bu}+100 \mathrm{ppm} \mathrm{Al}_{2} \mathrm{O}_{3}$ blends would give better spray characteristics than only butanol-biofuel blends.

The calorific value was decreased by $6.1 \%$ when $10 \%$ butanol was added to B 100 Figures 6(c) and 6(d). This was due to the low calorific value of butanol being $37.334 \frac{\mathrm{MJ}}{\mathrm{kg}}[21]$. The same happened with RS100 when 10\% Bu was added (from RSO100 to RSO90Bu10), the calorific value was decreased by $2.8 \%$. 
In general, for all blends the calorific value increased when $100 \mathrm{ppm} \mathrm{Al}_{2} \mathrm{O}_{3}$ were added. The increase in $\mathrm{HHV}$ for $\mathrm{B} 100$ and $\mathrm{B} 90 \mathrm{Bu} 10$ fuels were $5.8 \%$ and $9.6 \%$ respectively when $100 \mathrm{ppm} \mathrm{Al}_{2} \mathrm{O}_{3}$ were added. On the other hand, these values were $7.2 \%$ and $8.2 \%$ for RSO100 and RSO90Bu10 when 100 ppm $\mathrm{Al}_{2} \mathrm{O}_{3}$ were added Figure 6(d). These results proved that rate of increase in HHV were higher when nanoparticles were added in the biofuel -butanol blends instead of only neat biofuels. Hence, it was evident that the butanol was able to help catalyse the combustion process much better in the nanoparticles blends. Macroscopic spray characteristics with and without $\mathrm{Al}_{2} \mathrm{O}_{3}$ nanoparticles are shown in Figure 7.

When 10\% Butanol was added to B100 (from B100 to B90Bu10), liquid sheet angle stayed the same. On the other hand, when 10\% Butanol was added to RSO100 (from RSO100 to RSO90Bu10), the liquid sheet angle increased by 25\% (Figure 7(a)). Furthermore, when $\mathrm{Bu}$ was added to the biofuels with $\mathrm{Al}_{2} \mathrm{O}_{3}$ blends, the liquid sheet angle increased by $23.1 \%$ for $\mathrm{B} 90 \mathrm{Bu} 10+100 \mathrm{ppm} \mathrm{Al}_{2} \mathrm{O}_{3}$ when compared to $\mathrm{B} 90 \mathrm{Bu} 10$; and $11.1 \%$ for $\mathrm{RSO} 90 \mathrm{Bu} 10+100 \mathrm{ppm} \mathrm{Al}_{2} \mathrm{O}_{3}$ when compared to $\mathrm{RSO} 90 \mathrm{Bu} 10$. The decrease for $\mathrm{B} 100$ when $100 \mathrm{ppm} \mathrm{Al}_{2} \mathrm{O}_{3}$ were added was $40 \%$, and this value was $16.7 \%$ for RSO100 when $100 \mathrm{ppm} \mathrm{Al}_{2} \mathrm{O}_{3}$ were added (Figure 7(a)).

The results illustrated that overall, Butanol - biofuel - nanoparticle blends gave increased liquid sheet angle; this will eventually lead to improved combustion inside the engine cylinder and lower fuel consumption. The spray cone angle increased by $0.19 \%$ when $10 \%$ Butanol was added to B100 (from B100 to B90Bu10) - Figure 7 (b). Whereas, this was decreased by $21.4 \%$ in the case of RSO100. When Bu was added to the biofuels with $\mathrm{Al}_{2} \mathrm{O}_{3}$ blends, the spray cone angle increased by $19.5 \%$ for $\mathrm{B} 90 \mathrm{Bu} 10+100 \mathrm{ppm} \mathrm{Al}_{2} \mathrm{O}_{3}$ when compared to $\mathrm{B} 90 \mathrm{Bu} 10$, and by $22.3 \%$ for $\mathrm{RSO} 90 \mathrm{Bu} 10+100 \mathrm{ppm} \mathrm{Al}_{2} \mathrm{O}_{3}$ when compared to RSO90Bu10. The spray characterisation results proved that butanol - nanoparticle blends gave better spray characteristics than only nanoparticles-biofuels blends. The increase in the liquid sheet angle and the spray cone angle would mean that the atomisation of the fuels would be better as more fuel particles will get in contact with air. 


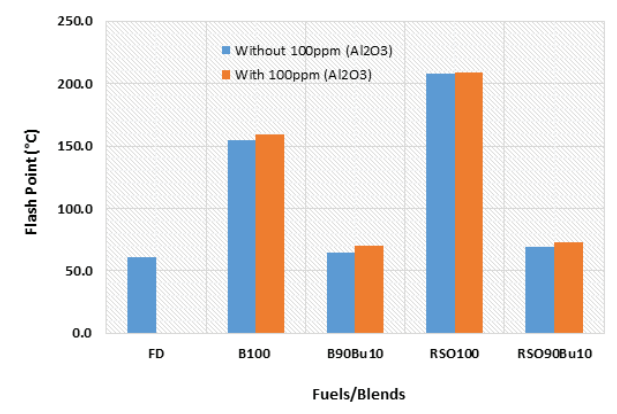

(a) Flash point with \& without 100 ppm $\mathrm{Al}_{2} \mathrm{O}_{3}$

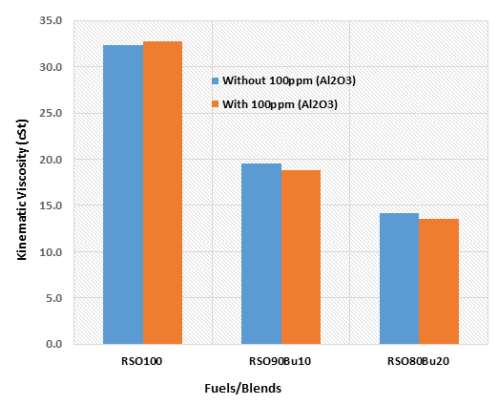

(c) Viscosity @ $40^{\circ} \mathrm{C}$ of RSO \& butanol blends - with \& without the addition of $100 \mathrm{ppm} \mathrm{Al}_{2} \mathrm{O}_{3}$

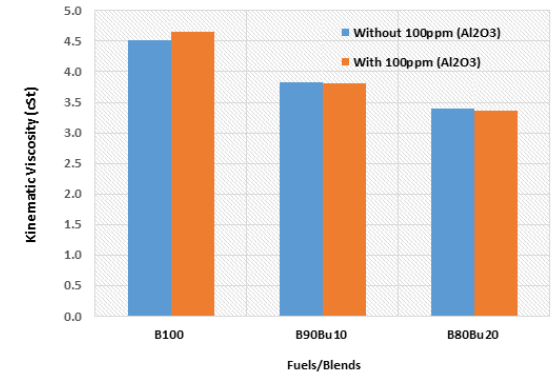

(b) Viscosity @ $40^{\circ} \mathrm{C}$ with \& without $100 \mathrm{ppm} \mathrm{Al}_{2} \mathrm{O}_{3}$

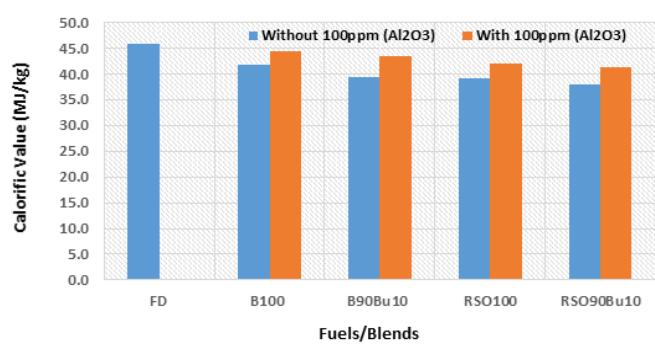

(d) Calorific value of blends with \& without 100ppm $\mathrm{Al}_{2} \mathrm{O}_{3}$

Figure 6 - Comparison of biofuels (and blends) properties with and without $\mathrm{Al}_{2} \mathrm{O}_{3}$ nanoparticles

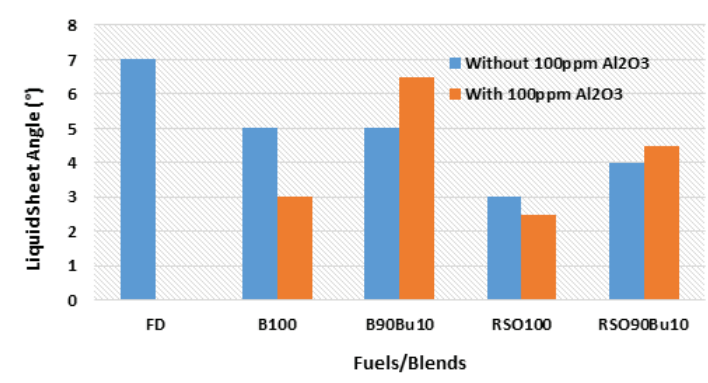

(a) Liquid sheet angle of blends with \& without 100ppm $\mathrm{Al}_{2} \mathrm{O}_{3}$

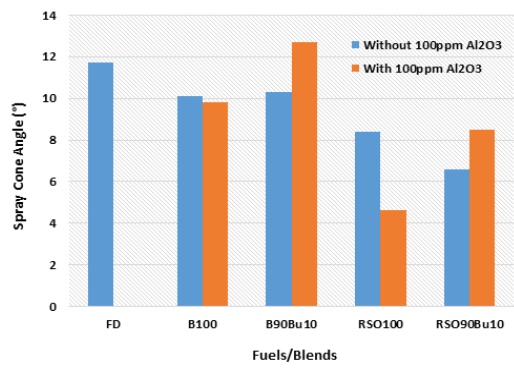

(b) Spray cone angle of blends with \& without $100 \mathrm{ppm} \mathrm{Al}_{2} \mathrm{O}_{3}$

Figure 7 - Spray properties of fuels with and without $\mathrm{Al}_{2} \mathrm{O}_{3}$ nanoparticles 


\section{CONCLUSIONS}

Two nanoparticles $\left(\mathrm{Al}_{2} \mathrm{O}_{3}\right.$ and $\left.\mathrm{CuO}\right)$ were used in this study to investigate the physicochemical properties and spray characteristics of the biofuel blends. It was found that the addition of nanoparticles increased the density, flash point temperature, kinematic viscosity and heating value of the fuels when mixed separately with neat FD, neat B100 and neat RSO100.

The density of the $\mathrm{Al}_{2} \mathrm{O}_{3}$ blends were lower than $\mathrm{CuO}$ blends. The flash point were much higher for $\mathrm{Al}_{2} \mathrm{O}_{3}$ blends in comparison to $\mathrm{CuO}$ blends. The viscosity was increased with both nanoparticles; however, $\mathrm{Al}_{2} \mathrm{O}_{3}$ gave smaller increase than $\mathrm{CuO}$ nanoparticles. It was proved that addition of $\mathrm{Al}_{2} \mathrm{O}_{3}$ gave better properties than $\mathrm{CuO}$ nanoparticles.

For internal combustion engines application, increase in the density and the viscosity would produce negative effects on engine fuel supply systems and combustion; whereas, on the other hand, increased flash point and the heating value would produce positive effects on fuel systems and combustion.

Hence, in the second stage of the study, the effect of butanol addition in $\mathrm{Al}_{2} \mathrm{O}_{3}$ nanoparticles-biofuels were assessed to see how butanol addition affect physicochemical properties and spray characteristics of the blends. It was observed that Butanol-biofuel- $\mathrm{Al}_{2} \mathrm{O}_{3}$ blends improved physicochemical properties and spray characteristics when compared to only biofuel- $\mathrm{Al}_{2} \mathrm{O}_{3}$ blends. The spray characteristic results showed that both spray cone angle and the liquid sheet angle parameters were improved significantly for $\mathrm{Al}_{2} \mathrm{O}_{3}$ - butanol - biofuel blends. The study concluded that addition of butanol helped to emulsify $\mathrm{Al}_{2} \mathrm{O}_{3}$ nanoparticles effectively in the blends; and butanol can be used as a surfactant for emulsification of $\mathrm{Al}_{2} \mathrm{O}_{3}$ nanoparticles in biofuels. Measurement of surface tension, engine performance and exhaust emission analysis are recommended as further work. Use of other nanoparticles and ethanol is another area of further investigation. 


\section{REFERENCES}

[1] Smith H, Winfield J, Thompson L. The market for biodiesel production from used cooking oils and fats, oils and greases in London. LRS consultancy, 2013.

[2] Challenges and opportunities-Understanding the Basic Properties of Nanoparticles. https://web.phys.ksu.edu/current/seminar/s09/mody-per-seminar.pdf

[3] AZO Nano. Copper Oxide (CuO) Nanoparticles - Properties, Applications; 2013. http://www.azonano.com/article.aspx?ArticleID=3395

[4] Gan Y, Qiao L. Combustion characteristics of fuel droplets with addition of nano and micronsized aluminium particles. Combustion and Flame 2011; 158(2): 354-368.

[5] Soutter W. Nanoparticles as Fuel Additives. AZO NANO; 2012.

[6] Samuel N, Shefeek MK. Performance and Emission Characteristics of a C.I Engine with Cerium Oxide Nanoparticles as Additive to Diesel. Int. J. Sci \& Res 2015; 4(7): 673-676.

[7] Gumus S, Ozcan H, Ozbey M, Topaloglu B. Aluminium oxide and copper oxide nanodiesel fuel properties and usage in a compression ignition engine. Fuel 2016; 163: 80-87.

[8] Santhanamuthu M, Chittibabu S, Tamizharasan T, Mani TP. Evaluation of CI engine performance fuelled by Diesel-Polanga oil blends doped with iron oxide nanoparticles. Int. J. ChemTech Res 2014; 6 (2): 1299-1308.

[9] D'Silva R, Binu KG, Bhat T. Performance and Emission Characteristics of a C.I engine fuel with diesel and TiO nanoparticle as additives. Mat. Today: Proc 2015; 2(4-5):3728-3735.

[10] George RO, James SJ, Franc S, John M. An Experimental Analysis on Synergetic Effect of Multiple Nanoparticle Blended Diesel Fuel on CI Engine. IJIRST 2015; 1(12).

[11] Aalam S, Saravanan CG. Effects of nano metal oxide blended Mahua biodiesel on CRDI diesel engine. Ain Shams Engg Journal 2015 (in press).

[12] Aalam CS, Saravanan CG. Performance Enhancement of Common-Rail Diesel Engine using A12O3 and Fe3O4 Nanoparticles Blended Biodiesel. IRJET 2015;2(5): 1400-1410.

[13] Wang X, Huang Z, Kuti OA, Zhang W, Nishida K. Experimental and analytical study on biodiesel and diesel spray characteristics under ultra-high injection pressure. Int J Heat Fluid Flow 2010;31(4):659-666.

[14] Ejim CE, Fleck BA, Amirfazli A. Analytical study for atomization of biodiesels and their blends in a typical injector:Surface tension and viscosity effects. Fuel 2007;86(10):1534-1544. 
[15] Şahin Z, Aksu O. Experimental investigation of the effects of using low ratio n-butanol/diesel fuel blends on engine performance and exhaust emissions in a turbocharged DI diesel engine. Ren Energy 2015; 77: 279-290.

[16] Tücca, G, Özgür T, Aydın K. Effect of diesel-microalgae biodiesel-butanol blends on performance and emissions of diesel engine. Fuel 2014; 132: 47-52.

[17] Wolfrom MathWorld. http://mathworld.wolfram.com/Cone.html

[18] Sigma-Aldrich.

http://www.sigmaaldrich.com/catalog/product/aldrich/544868?lang=en\&region=GB

[19]

Sigma-Aldrich

http://www.sigmaaldrich.com/catalog/product/aldrich/544833?lang=en\&region=GB

[20] Chhetri AB, Watts KC. Surface tensions of petro-diesel, canola, jatropha and soapnut biodiesel fuels at elevated temperatures and pressures. Fuel 2013;104 (1):704-710.

[21] Rakopoulos DC, Rakopoulos CD, Giakoumis EG, Dimaratos AM, Kyritsis DC. Effects of butanol-diesel fuel blends on the performance and emissions of a high-speed DI diesel engine. Ener Con and Management 2010;51:1989-1997.

[22] Mužíková Z, Šimáček P, Pospíšil M, Šebor G. Density, Viscosity and Water Phase Stability of 1-Butanol-Gasoline Blends. Journal of Fuels 2014; 2014 p. 7, 2014. 